\title{
Asthma, chronic obstructive pulmonary disease (COPD) and asthma-COPD overlap syndrome and the risk of severe COVID-19
}

\author{
Astma, przewlekła obturacyjna choroba płuc (POChP), zespół \\ współistnienia astmy i POChP a ryzyko ciężkiego przebiegu COVID-19
}

\author{
Klaudia Waszczykowska, Marta Węgierska, Roxana Drygała, Rafał Pawliczak \\ Department of Immunopathology, Medical Faculty, Medical University of Lodz, Lodz, Poland
}

\begin{abstract}
Asthma, chronic obstructive pulmonary disease (COPD) and asthma-COPD overlap syndrome (ACOS) significantly affect the patient's respiratory system, which requires individualised treatment and professional control. During the SARS-CoV-2 pandemic, all respiratory diseases were taken into consideration as risk factors for severe COVID-19. ACE2 and TMPRSS2 genes, which are crucial for SARS-CoV-2 to enter the host cell, have different expression in the occurrence of asthma or COPD. Also, comparing the severity and mortality of patients with coexistence of asthma or COPD and COVID-19, only COPD patients had worse outcomes of COVID-19, and their mortality was significantly higher. Although ACOS is also a potential risk factor for hospitalisation and mortality in COVID-19 patients, the condition still requires further studies. This overview presents the current state of knowledge on the relationship between the diseases mentioned above and COVID-19.
\end{abstract}

\section{KEY WORDS}

bronchial asthma, chronic obstructive pulmonary disease (COPD), asthma-COPD overlap syndrome, COVID-19, SARS-CoV-2.

\section{STRESZCZENIE}

Astma, przewlekła obturacyjna choroba płuc (POChP) oraz zespół nakładania astmy i POChP (ACOS) znacząco wpływają na układ oddechowy pacjentów, co wymaga indywidualnego leczenia oraz specjalistycznej kontroli. W czasie pandemii SARS-CoV-2 wszelkie choroby związane z układem oddechowym zostały wzięte pod uwagę jako czynniki ryzyka ciężkiego przebiegu COVID-19. Potwierdzono, że geny ACE2 i TMPRSS2, kluczowe dla infekcji SARS-CoV-2, wykazują różną ekspresję w przypadku astmy i POChP. Ponadto, porównując ciężkość przebiegu COVID-19 oraz śmiertelność pacjentów cierpiących jednocześnie na COVID-19 i astmę lub POChP, tylko u chorych na POChP stwierdzono istotnie zwiększoną śmiertelność. Również ACOS jest potencjalnym czynnikiem ryzyka hospitalizacji i śmiertelności pacjentów z COVID-19, jednak nadal wymaga on dalszych badań. W niniejszej pracy przedstawiono aktualny stan wiedzy na temat związku między wspomnianymi chorobami a COVID-19. 


\section{SŁOWA KLUCZOWE}

astma oskrzelowa, przewlekła obturacyjna choroba płuc (POChP), zespół nakładania się astmy i POChP, COVID-19, SARS-CoV-2.

\section{ADDRESS FOR CORRESPONDENCE:}

Prof. Rafał Pawliczak MD, PhD, Department of Immunopathology, Division of Allergology, Immunology and Dermatology, Faculty of Biomedical Sciences and Postgraduate Training, Medical University of Lodz, 7/9 Zeligowskiego St, Building 2, Room 177, PL-90-752 Lodz, Poland, phone: +48 4227252 75, +48 4227252 76, fax: +48 4227252 75, e-mail: rafal.pawliczak@csk.umed.lodz.pl

\section{INTRODUCTION}

Asthma affects 339 million people, while patients suffering from chronic obstructive pulmonary disease (COPD) are estimated to number over 329 million worldwide $[1,2]$. Also, these two conditions may occur simultaneously, as asthma-COPD overlap syndrome (ACOS). It is hard to estimate the precise occurrence of these diseases due to the similarity of the symptoms. ACOS is an even more serious condition than asthma or COPD alone, meaning that the exacerbations may be more frequent and severe. SARS-CoV-2 infection, being the reason behind COVID-19, similarly to asthma and COPD focuses on the lungs. Currently, researchers are trying to investigate the relationship between these conditions and the severity of COVID-19. In this paper, the diseases are briefly characterized along with their overlap, including the risk of severe COVID occurrence [3].

\section{COVID-19}

\section{MOLECULAR BASIS}

Severe acute respiratory syndrome coronavirus 2 (SARS-CoV-2) is an RNA virus with positive single-stranded genomic RNA and two characteristic envelope proteins - the spike glycoprotein (S) and the transmembrane glycoprotein $(\mathrm{M})$. The $S$ glycoprotein is necessary to bind to the human angiotensin-converting enzyme 2 (ACE2), which provides the entry point for the virus by being an attachment site for the virus. On the other hand, the $\mathrm{M}$ glycoprotein is responsible for envelope formation and virion assembly [4]. During viral entry, presence of human transmembrane serine protease 2 (TMPRSS2) is also crucial. TMPRSS2 activates the internalization of the virus by cleavage of the spike protein. TMPRSS2 and ACE2 are necessary for the SARS-CoV-2 virus to enter the host cell. According to this fact, it is thought that the expression level of these proteins can influence the course of COVID-19 [5].
The pathogenesis of COVID-19 is based on the pro-inflammatory responses to viral infection while for example cytokines and chemokines, such as tumour necrosis factor (TNF), interleukin 2 (IL-2), IL-7, IL-10 or granulocyte colony-stimulating factor (G-CSF) and more, are released by the infected cell. During SARS-CoV-2 infection one is likely to observe rapidly developing inflammation caused by the "cytokine storm" (Figure 1). Although this kind of immune response is common during viral infections, in some cases SARS-CoV-2 can lead to excessive cytokine release in cells of an infected organ. Prolonged and intensive inflammation results in organ damage or even failure [6]. Depending on the intensity of inflammation occurring among COVID-19 patients, symptoms can be diverse, from mild to moderate or even severe. The more proinflammatory molecules released during the infection, the more severe is the disease manifestation observed $[6,7]$.

\section{EPIDEMIOLOGY}

Coronavirus disease-19 (COVID-19) was identified for the first time in China in December 2019 when a huge pneumonia outbreak was observed. Researchers found out that COVID-19 is caused by the novel severe acute respiratory syndrome coronavirus 2 (SARS-CoV-2) infection transmitted through the respiratory tract [4]. According to World Health Organization data to date, the only continent which has no identified COVID-19 cases is Antarctica. So far, new COVID-19 cases and deaths among COVID-19 patients are increasing day by day [8]. COVID-19 is observed among every possible age group and its frequency is not age-dependent. Although anyone can be infected with SARS-CoV-2, the mortality of COVID-19 is significantly higher among patients aged 60 and older [9]. On the other hand, coexisting chronic diseases such as cardiovascular diseases, diabetes, and chronic obstructive pulmonary disease (COPD) increase the disease severity and death rate among COVID-19 


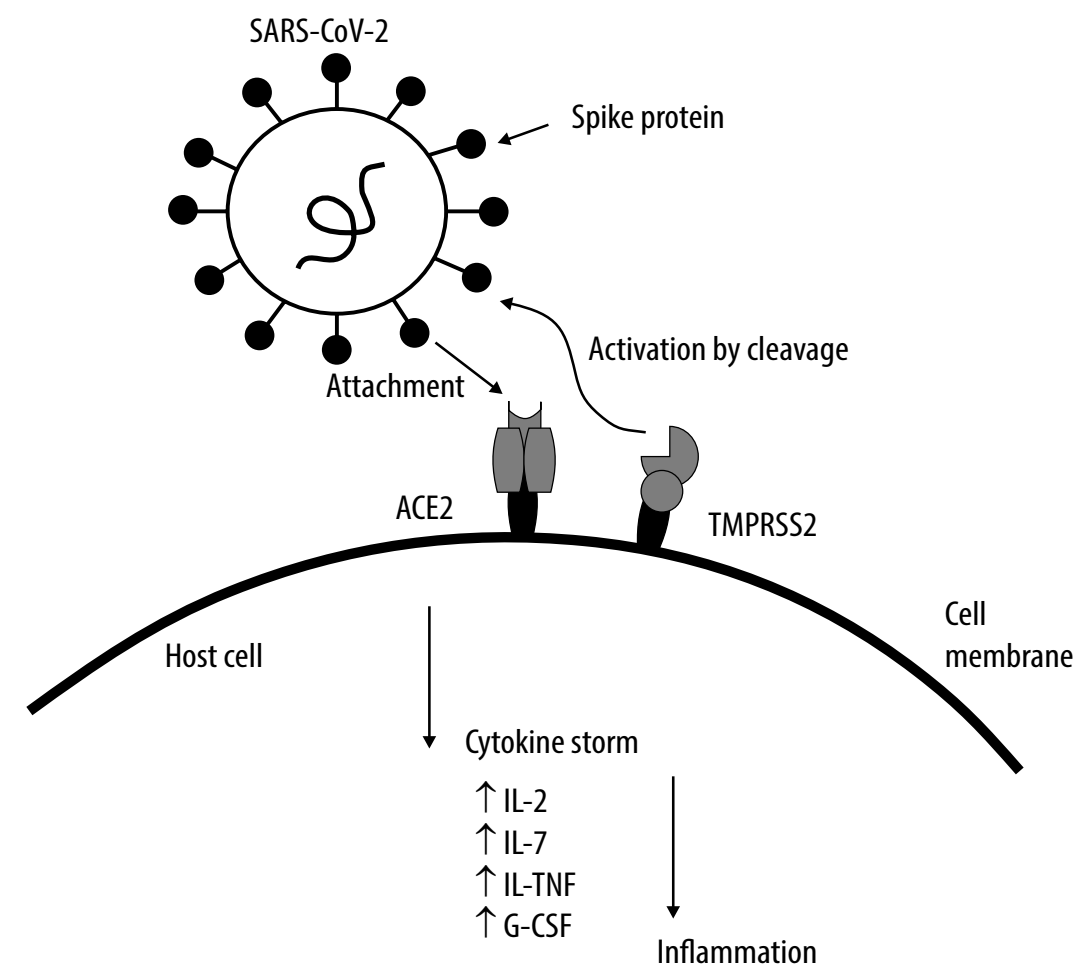

FIGURE 1. Molecular mechanism of SARS-CoV-2 infection

patients [10]. These observations indicate that older patients and those suffering from chronic diseases should be urgently hospitalized in case of being infected with SARS-CoV-2.

\section{SYMPTOMS}

Symptoms of COVID-19 are very similar to those observed among patients with seasonal flu. The most frequently occurring are fever, cough, tiredness and shortness of breath [4]. Their manifestation occurs approximately 5 days after the infection, which is a period of SARS-CoV-2 incubation [11]. In most COVID-19 patients, symptoms are from mild to moderate and they do not require any urgent medical help. Unfortunately, some patients require hospitalization because of the severity of occurring symptoms such as chest pain and difficulties with breathing [4]. Considering that SARS-CoV-2 spreads mainly through the respiratory tract, the lungs are the most exposed organs during this viral infection. Among hospitalized patients with COVID-19 acute lung injuries were observed during lung biopsy $[9,12]$.

It is also reported that when the infection lasted shorter than 10 days, symptoms were less severe. During longer-lasting infection, for example acute bronchopneumonia, organizing pneumonia or type II hyperplasia developed among COVID-19 patients. To date, the most frequently reported are mid-sized pulmonary endothelial damage, pulmonary infarcts and vascular fibrin thrombi
[13]. COVID-19 symptoms do not involve only pulmonary tissues. It is also observed that other tissues can be damaged during SARS-CoV-2 infection due to excessive inflammatory processes. High levels of serum cytokines are correlated with extrapulmonary organ failure among COVID-19 patients [6].

\section{DIAGNOSIS}

The diagnosis of COVID-19 is performed using two tests which are the RT-PCR test as a molecular diagnostic method and the serological test. The RT-PCR test allows viral genetic material to be detected in specimens taken from the upper and lower respiratory tract. The sensitivity of this test seems to be high, but it is still possible to obtain false-positive and false-negative results depending on the tested specimens. This method is currently the best diagnostic tool to detect early infection and active viral shedding, which helps to identify infected patients and allows one to take measures to limit further spread of the virus $[4,12]$.

The serological test is based on the detection of antibodies against viral proteins. Unfortunately, this type of test will give reliable results approximately 2 weeks after the SARS-CoV-2 infection, when specific antibodies are produced. It means that the serological test cannot be used as a diagnostic tool at early stages of infection and cannot be used to prevent viral shedding. Both tests combined together seem to have the highest sensitivity 
of diagnosis. The RT-PCR test is the best method for rapid detection of SARS-CoV-2 at the early stage of infection, which is highly important to prevent dissemination of the disease. Immune tests do not play a key role during epidemic prevention but can be important during the second recurrence of this virus among patients [4].

\section{TREATMENT}

From the very first day of the coronavirus epidemic, researchers have been looking for the best treatment for COVID-19. Most of the currently used treatment methods are focused on reducing the level of proinflammatory cytokines. Some of them are corticosteroids, IFN- $\gamma$, IL-1 family antagonists, IL-6 antagonists, ulinastatin and even stem cell therapy or blood purification treatment [6].

Anti-viral drugs also seem to have potential as a therapeutic approach in COVID-19 treatment and the most promising are for example remdesivir, chloroquine, hydroxychloroquine, ribavirin. The foregoing potential drugs (which are only a small amount of possible drugs for SARSCoV-2 infections available on the market) are not accepted as effective approaches to treat COVID-19 patients. There is still a need to develop an appropriate medical treatment or preventive vaccinations for COVID-19 [14].

\section{THE ASSOCIATION BETWEEN SMOKING AND COVID-19}

At the outset of the SARS-CoV-2 pandemic, smoking was expected to be a risk factor increasing the susceptibility to infection with the virus [15].

To evaluate these suspicions, a huge cohort study was conducted where researchers tested the correlation between active smoking with susceptibility to infection and clinical outcomes of patients with COVID-19. They observed that a substantial majority of tested smokers were diagnosed negative to SARS-CoV-2 in comparison to positive cases (4734 $(13.45 \%)$ vs. $103(4.55 \%), p<0.001)$. This observation may indicate that active smoking has a protective role during SARS-CoV-2 infection. Probably, in this case, the nicotinic acetylcholine receptor (nAChr) plays an important role in the pathogenesis of COVID-19. Considering that possibility, pharmacological nicotine could be supplemented as a preventive agent against SARS-CoV-2 infection [16]. Another study conducted by Usman et al. also showed that current smokers are less susceptible to SARS-CoV-2 infections, and suggested that nicotine can activate anti-inflammatory pathways [17].

Some studies have proposed that active smoking during COVID-19 may increase its severity and mortality rate, but further studies are needed to obtain more precise and reliable data [18].

\section{ASTHMA}

Bronchial asthma is a heterogeneous disease of chronic airway inflammation, with characteristic symptoms of wheezing, dyspnoea, cough, shortness of breath and chest tightness. One of the most vital risk factors triggering asthma is inhaled particles provoking allergic reactions, e.g. pollens, moulds, dust, tobacco smoke or other chemical irritants. About 339 million people had asthma and the disease caused over 400 hundred deaths globally in 2016 [19].

Chronic inflammation of the lower respiratory tract is dependent on the tilt of the Th2 lymphocyte balance. There are two most typical endotype groups in asthma categorization - Th2 high and non-Th2. Th2 high group contains atopic, late-onset and aspirin-exacerbated respiratory disease (AERD) phenotypes, while non-Th2 endotype consists of non-atopic, obesity-related and smoking-related phenotypes [20]. Atopic asthma characterized by a type 2 eosinophilic inflammation is present in more than $50 \%$ of diagnosed patients [21]. Allergic asthma has a Th2 profile of chronic lower respiratory tract infection, in which, by tilting the balance towards CD4 + lymphocytes having the Th2 phenotype, bronchial epithelium produces cytokines of this profile, which is characteristic of type I hypersensitivity - allergy.

At the beginning of the SARS-CoV-2 pandemic, asthma was one of the first diseases mentioned as a COVID-19 risk factor, as were other respiratory illnesses. Mild coronavirus strains frequently appear during an asthma exacerbation. In approximately $8.4 \%$ of the patients $(95 \% \mathrm{CI}, \mathrm{RR}=5.1,13.6)$, mild coronavirus strains were present, which justified its inclusion in the risk factor list [22]. It is not clear if SARS-CoV-2 causes asthma exacerbation and how the mechanism exactly works [23]. Based on present knowledge, $9 \%$ of mortality among patients with COVID-19 had asthma history [24]. The Green et al. cohort study with over 37000 subjects showed lower COVID-19 susceptibility in asthmatic patients $-6.75 \%$ of patients with asthma had a positive SARS-CoV-2 test, while $9.62 \%$ were in the SARS-CoV-2 negative group $(p<0.001)$ [16]. Previous studies have found no difference in hospitalization or mortality rate between COVID-19 patients with and without asthma $[25,26]$.

In some cases, asthma exacerbation is challenging to distinguish from COVID-19 acute respiratory distress syndrome (ARDS) because both conditions initially share common symptoms - dyspnoea and dry cough. These diseases are easier to differentiate without testing when patients experience loss of smell or taste, fever, or attenuation present among COVID-19 patients. The occurrence of wheezing is also common mostly in patients with asthma [27]. 
There is a hypothesis that tilting the balance in Th2 profile in allergic asthma may have a protective influence against severe COVID-19 because of the cross-regulation between allergic and interferon-mediated immune responses [20]. Th2 lymphocytes, which are specific for the allergen, arise from allergen presentation by dendritic cells, evolving from Th0 cells through the action of interleukin 4 (IL-4) produced by mast cells. IL-4 also regulates IgE production and the movement of eosinophilia into tissues, and also affects mast cells, making it a leading cytokine in the pathogenesis of allergies [28]. Even though asthmatics have a greater susceptibility to respiratory viral infections which may be a trigger for exacerbations, the Th2-dominant environment might be protective, particularly in the case in SARS-CoV infections [20].

\section{ASTHMA, OBESITY AND COVID-19}

It has been proved that obesity is a high-risk factor in hospitalization and mortality from COVID-19 infection, but the association strictly between asthma, obesity and COVID-19 is not fully discovered. Around 58\% of asthmatic individuals are obese [29]. Even though $26 \%$ of asthmatic patients require hospital admission due to poor prognosis after COVID-19, it is mostly associated with the main risk factors, including obesity, hypertension, diabetes and dyslipidaemia [30]. In patients aged 40 or older, the frequency of obesity was slightly higher among the group with asthma and a COVID-19-positive test (33.99\%) than those with a COVID-19-negative test (29.58\%) ( $p=0.002)$ [24].

The excess of adipose tissue and the adipokines it produces, such as IL- 6 and TNF- $\alpha$, may contribute to the formation of certain diseases and pathological conditions. Both of these factors increase the signal of inflammation in atopic asthma and lower symptoms control. There is a hypothesis that a high ACE2 concentration in visceral adipose tissue present in large amount in obese individuals may predispose to COVID-19 infection and development [16]. It seems clear that obesity increases the risk of mortality and hospitalization after SARS-CoV-2 infection, not just among asthmatic patients, but all individuals.

\section{BASIC ASTHMA TREATMENT}

The best treatment for asthmatics is proper medication and avoiding asthma triggers. The basic medication is pharmacotherapy based on the treatment of inflammation and minimizing the symptoms of asthma. For this purpose, two types of drugs are used: control and anti-inflammatory drugs (e.g. inhaled or systemic corticosteroids) and symptomatic drugs with a bronchodilator (e.g. $\beta 2$-agonists). There are also other types of medication, e.g. leu- kotriene receptor antagonists (LTRAs), which reduce the frequency of exacerbations and the severity of symptoms, but with weaker anti-inflammatory functionality than inhaled corticosteroids (ICS). Another type of treatment is biological therapy, which, by targeting specific inflammatory factors and reducing symptoms, provides more innovative solutions for the treatment of asthma [31].

\section{TREATMENT OF PATIENTS WITH ASTHMA AND COVID-19}

The risk of severe COVID-19 gets higher when asth$\mathrm{ma}$ is under control, so it is crucial to treat asthmatic patients with convenient medication, e.g. ICS, $\beta$-mimetics, LTRAs and biologicals.

If the asthmatic patient was infected with SARSCoV-2 and developed COVID-19, the medication should be consulted with an allergist or immunologist whether the present treatment is appropriate for each specific case. Experts of the Polish Allergy Society recommend that asthma patients should continue ICS treatment, regardless of whether the patient is infected or not. Disruption of the long-term use of glucocorticosteroids can only aggravate the patient's condition. Due to incomplete asthma control, coughing attacks support the spread of the virus among asymptomatic patients [23]. Treatment methods should not be changed among asthma patients who are COVID-19-positive. The Global Initiative for Asthma (GINA) recently stated that the suggestions about avoiding glucocorticosteroids during the COVID-19 pandemic apply mostly to the administration of systemic glucocorticosteroids, but not to inhaled ones. It is also recommended not to change treatment plans prescribed by the doctors and that patients should continue taking corticosteroids even if they are inhaled corticosteroids. In the case of acute asthma attacks, patients should use oral corticosteroids because inhaled corticosteroids may intensify COVID-19 exacerbation. Such administered corticosteroids should be used at the lowest possible dose [32].

Systemic corticosteroids are used chronically in around $5 \%$ of asthmatic patients and also in case of exacerbation of the disease. The World Health Organization recommends systemic corticosteroids rather than no corticosteroids if the patient is in a severe state of COVID-19, but not using this type of treatment of a patient in a mild state [33]. Because there is a small amount of data about COVID-19 treatment, it is not known whether the discouragement of oral corticosteroid treatment is due to the potential for harm to the patient or insufficient COVID-19 treatments [34].

Biologics are mostly recommended for patients with severe asthma for whom basic treatment has no positive effect. Most recommendations from the respiratory or- 
ganizations see no contraindications for using biologics in patients with COVID-19 and severe asthma. However, some patients may need a direct interaction for the administration of biologics [35].

\section{CHRONIC OBSTRUCTIVE PULMONARY DISEASE}

Chronic obstructive pulmonary disease (COPD) is a common worldwide disease whose symptoms can be treated to some point but is still a major cause of death. It is estimated that around 329 million people suffer from COPD, which accounts for almost $5 \%$ of the population [2].

The disease is characterized by developing a reduction of the expiratory airflow, which is coupled with chronic inflammation. The airflow limitation is not completely reversible and depends on the patient's age and the number of disease exacerbations. These events are usually a result of exposure to harmful particles and compounds contained in inhaled air. The most common example is tobacco smoke, but also several other risk factors can lead to development of the disease. These include indoor and outdoor air pollution, dust and chemicals in the workplace, as well as infections and existing medical conditions. It is estimated that about $20 \%$ of smokers suffer from COPD [36-38].

Development of COPD is associated with local inflammatory reactions in the lungs as a response to the inhalation of harmful substances. These events lead to direct damage of the lungs and progression of emphysema and fibrosis of the small airways, resulting in impaired gas exchange. The changes in the lungs include an increased amount of neutrophils, macrophages, T lymphocytes and B lymphocytes in the lumen. These inflammatory cells produce mediators enhancing the reaction and causing morphological remodelling of the surrounding tissues. The mediators involved in the pathogenesis include lipids, free radicals, cytokines and chemokines, as well as growth factors. In this case, blocking a single mediator would have no clinical impact [39].

As a result of impaired gas exchange, the most common symptoms of COPD are chronic shortness of breath (observed in more than $70 \%$ of cases), chronic cough (observed in around $60 \%$ of cases) and excess sputum production (observed in around 63\% of cases). These may occur even during walking or performing everyday activities. Less common symptoms include loss of appetite, loss of weight and swollen ankles [40].

\section{BASIC CHRONIC OBSTRUCTIVE PULMONARY DISEASE TREATMENT}

Similarly to the treatment of asthma, in COPD the key point of the treatment for people suffering from the disease is proper medication and avoiding the triggers, like smoking cessation. Another analogy is the use of corticosteroids and bronchodilators. In addition, mucolytics, which have been suggested to be more effective in cases with higher disease severity, could also be useful [41-43]. There is also limited evidence that influenza vaccination may be beneficial in the patients, mainly because of lowering the risk of exacerbations. In addition, physical inactivity is linked with an increased chance of hospitalization and mortality. It is recommended to perform at least walking every day, coupled with pulmonary rehabilitation for exercise tolerance. Moreover, patients with disabilities such as severe resting hypoxaemia, pulmonary hypertension, polycythaemia or possible heart failure are likely to benefit from long-term oxygen therapy [44].

Contrary to asthma, the positive influence of ICS usage in COPD patients is obscure and should not be implied unless the situation is urgent with frequent and symptomatic exacerbations. Compared to inhaled corticosteroids coupled with long-acting $\beta 2$-agonists, dual long-acting bronchodilators may exhibit a more significant reduction of exacerbation frequency, while bearing a lower risk of pneumonia. However, sometimes it may be necessary to continue ICS-including therapy in case of good symptoms control [45].

\section{COPD/COVID-19 COEXISTENCE}

Because of the nature of COPD, patients suffering from the disease are more vulnerable to respiratory tract infections, including SARS-CoV-2. Similarly as in asth$\mathrm{ma}$, coronaviruses tend to be a periodic cause of acute COPD exacerbations (AECOPD). Currently, opinions diverge as to whether the exacerbations should be attributed to the COPD in a COVID-19 patient. Probably, in case of COVID-19/COPD coexistence, it should be considered as a different condition than a typical AECOPD, since the pathophysiological process differs. It is observed that among hospitalized patients, the occurrence of COPD is significantly correlated with higher severity of COVID-19 symptoms, leading to a worse clinical outcome. The mortality rate was also significantly increased in the case of co-occurrence of COVID-19 and COPD. Every fourth patient who died during COVID-19 was diagnosed with COPD, while only $2.8 \%$ of patients diagnosed with both diseases survived $[46,47]$.

\section{TREATMENT OF PATIENTS WITH COPD AND COVID-19}

Studies indicate that severe COVID-19 has a higher chance of occurrence in COPD patients. Thus, the proper management of both diseases is of great importance. Symptoms which are valuable in distinguishing COPD 
exacerbation from SARS-CoV-2 infection include fever, anorexia, myalgias and gastrointestinal problems, which are usually not present in COPD [48].

Because corticosteroids are often prescribed for COPD patients, it is important to evaluate the risk associated with the administration of the drugs in COVID-19 coexistence. The WHO has recently warned about the use of corticosteroids in COVID-19, due to the poor effectiveness coupled with the risk of a potentially harmful outcome, as it was reported in past literature according to other viral pneumonia outbreaks such as SARS-CoV.

In COPD patients, using short-acting $\beta$-agonists is valid when the symptoms become intensified. If the patients experience acute exacerbation due to COVID-19 existence, there is no need to immediately apply a diverse medication approach. Similarly, as in asthma, every patient should follow an individual, personalized treatment, which may also include the use of corticosteroids. In the presence of COVID-19, patients should consult a doctor, as it is not recommended to introduce oral corticosteroids into the treatment by the patient alone, even in short-term therapy. Delaying the therapy is not recommended, as severe exacerbations may occur in this time. Short-term use of oral corticosteroids is favourable in the resolution of more severe disease symptoms and can be abandoned suddenly, as the exacerbations vanish [45].

Summing up, treatment methods have not changed among COPD patients who are COVID-19-positive. The Global Initiative for Chronic Obstructive Lung Disease (Gold) recommended to keep taking drugs as prescribed and not to change their administration type [49].

\section{ACOS - ASTHMA AND CHRONIC OBSTRUCTIVE PULMONARY DISEASE OVERLAP}

Asthma and chronic obstructive pulmonary disease (COPD) have been recognized for years as two separate diseases. Due to the similarity of symptoms, the differentiation between asthma and chronic obstructive pulmonary disease is still a problem in clinical practice. In fact, the main differentiating factor between COPD and asthma is the lack of complete reversibility of airflow limitation in the airways, regardless of the presence of chronic cough, excessive sputum and the presence of emphysema. In the case of asthma, the obstruction is usually reversible. However, if not treated properly, chronic asthma inflammation can lead to irreversible narrowing of the airways due to changes in their structure.

Moreover, in many situations, both conditions may occur simultaneously. In such cases, the disease is called asthma-chronic obstructive pulmonary disease overlap syndrome (ACOS). ACOS is an even more serious condition than asthma or COPD alone, meaning that the exacerbations may be more frequent and severe $[3,36]$.

COPD coexistence in asthma patients suffering from COVID-19 was evaluated as a potential risk factor for hospitalization and mortality. The study, along with COPD comorbidity, also investigated other potential risk factors such as age, sex, race, presence of diabetes mellitus or cardiovascular diseases and more. In these patients, the study suggests that coexistence of COPD may be a potent risk factor for hospitalization (adjusted $\mathrm{OR}=1.92$, $\mathrm{CI}=95 \%, \mathrm{RR}=1.35-2.72, p<0.001)$. Moreover, it was found to be the only statistically significant value after correction for multiple comparisons $(p<0.05)$. According to the study, it is important to distinguish asthma between other chronic pulmonary diseases during research, as its coexistence with COPD may be of great importance for estimation of the risk of severe COVID-19 [50].

Studies reviewing the SARS-CoV-2 infection in the ACOS condition also include single cases. One of them, analysed by Aksan et al., investigated a case of an obese female smoker in her forties with hypertension. The COVID-19 symptoms consisted of absence of a sense of taste or smell, dry cough, dyspnoea and body aches with chills. As the disease progressed, also intense and burning pain of the neck and back occurred, which was intensified by touch or warmth. However, it is probably not attributable to the presence of ACOS. During the infection, the patient was treated with prednisone, ipratropium and albuterol for exacerbations caused by COPD and asthma. Still, the study reports no intensification of the ACOS exacerbations during the SARS-CoV-2 infection [51].

Another case study, analysed by Lau et al., focuses on the SARS-CoV-2 infection in a 77-year-old man with ACOS. The patient was diagnosed with progressive cough and worsening shortness of breath, with desaturation. Intensification of these symptoms during the viral infection, along with desaturation, was a sign to perform computed tomography (CT) of the thorax on the fourteenth day of illness. It revealed subpleural interstitial thickening. However, no peribronchial thickening correlated with the presence of ACOS was observed on CT. Still, the authors suggested that the asthma-COPD overlap syndrome partially contributed to the patient's desaturation [52].

\section{DIFFERENCES IN ACE2 AND TMPRSS2 EXPRESSION AMONG COPD AND ASTHMATIC PATIENTS}

According to current studies, it is observed that COPD patients suffer more severe symptoms of COVID-19, while most of the asthmatic patients do not demonstrate a significant difference compared to patients without any chronic pulmonary diseases [46]. 
Considering the fact that SARS-CoV-2 needs the presence of ACE2 to enter the host cells, expression levels of ACE2 among COPD and asthmatic patients were analysed. Two different studies have shown that ACE2 expression in epithelium of the bronchioles was significantly higher among COPD patients and lower or higher among asthmatic patients. Both groups were compared to patients with no chronic pulmonary disease diagnosed $[53,54]$.

It is hypothesized that different endotypes of asthma may modify ACE2 expression differently, thereby affecting COVID-19. Some cytokines typical for particular asthma endotypes can lead to upregulation of expression of ACE2, such as IL-17, and some can cause downregulation of this receptor, for example, IL-4 and IL-13 [55].

Such observations may indicate that viral entry to the host cells can be facilitated thanks to higher expression of ACE2, which probably leads to more severe COVID-19 symptoms among COPD patients. The opposite tendency in the expression of ACE2 among some asthmatic patients may have some protective contribution during COVID-19 because the viral entry is not as easy as in case of the normal expression level of ACE2 [53, 56].

TMPRSS2 expression was also analysed among COPD and allergic asthma patients. Both conducted studies showed that the expression of TMPRSS2 is increased in both groups compared to healthy individuals. Knowing the function of TMPRSS2 during viral entry to the host cells, upregulation of TMPRSS2 expression seems to be more crucial during developing more severe COVID-19 symptoms and the overall course of disease than differences in expression of ACE2 [57, 58].

Considering current data, it seems that patients with asthma and patients with COPD may experience a different course of COVID-19. Even though the ACE2 and TMPRSS2 expression differs between COPD and asthmatic patients, changes in biological parameters and inflammation developed during SARS-CoV-2 infection can worsen symptoms which are already observed in both groups (Table 1) [56, 59].

Further studies based on differences in ACE2 and TMPRSS2 expression are needed to fully understand the underlying mechanism of developing more severe symptoms of COVID-19 among COPD and asthmatic patients. Such knowledge would help to develop new therapeutic approaches during COVID-19 treatment.

\section{CONCLUSIONS}

According to current knowledge, the co-occurrence of chronic respiratory diseases has an impact on COVID-19 susceptibility. The leading cause is that occurrence of asthma or COPD leads to different expression of both genes ACE2 and TMPRSS2 that are crucial for SARS-CoV-2 to enter the host cell. Chronic obstructive pulmonary disease is one of the factors that significantly increase the risk of infection with SARS-CoV-2, while asthma is mainly thought to decrease COVID-19 susceptibility among patients $[5,57]$.

Comparing the severity and mortality of patients with co-occurrence of asthma or COPD and COVID-19, only COPD patients had worse outcomes of the COVID-19 and their mortality was significantly higher. Asthma seems not to change either mortality or severity among patients with COVID-19 [18, 25].

Co-occurrence of ACOS and COVID-19 requires further studies because asthma/COPD overlap syndrome has no efficient and appropriate diagnostic tools to identify which patients have ACOS [50].

Surprisingly, smokers also seem to be less susceptible to SARS-CoV-2 infection according to the studies conducted by Green et al. Surely we cannot look upon smoking as a preventive method against COVID-19 development. Nicotine itself is thought to have a protective role during SARS-CoV-2 infection, but there are also other methods, which can prove better and more efficacious [16].

On the other hand, current smokers may suffer more severe symptoms of COVID-19, leading to a higher mortality rate among COVID-19 patients. However, this issue has to be studied on a larger cohort to obtain reliable data. After all, discontinuation of smoking during COVID-19 seems to be good advice to avoid any possible severe complications of COVID-19 [18].

According to GINA and GOLD, both asthma and COPD patients should maintain their current treatments during COVID-19. All necessary changes in the medication should be consulted with a specialist $[32,49]$.

At present, European data are very scarce, and most of the information is derived from Asian research. Given both social and genetic differences between the two populations, Asian data may not be fully mapped to the European population. In some European countries,

TABLE 1. Differences in ACE2 and TMPRSS2 expression in COPD, neutrophilic and eosinophilic asthma [59]

\begin{tabular}{|l|c|c|c|}
\hline Expression & COPD & Neutrophilic asthma & Eosinophilic asthma \\
\hline ACE2 & Upregulated & Upregulated & Downregulated \\
\hline TMPRSS2 & Upregulated & Upregulated $^{*}$ & Upregulated $^{*}$ \\
\hline
\end{tabular}

*The more severe the asthma, the higher the expression of TMPRSS2. 
data about the concomitant diseases in COVID-19 patients are no longer gathered, which can hamper future analysis and conclusions. Also, some studies emphasize distinguishing asthma and COPD from each other, as well as from other chronic pulmonary diseases during research, as their coexistence with different pulmonary conditions may be of great importance for the severe COVID risk estimation. Forthcoming studies should focus on identifying the immunopathology of exacerbation of these three diseases related to COVID-19. These studies would help in the determination of the best approaches to the patients' management. Also, with better diagnostic tools and greater conscientiousness in diagnosing both of these diseases, we would be able to estimate the risk of severe COVID-19 more precisely in particular cases.

\section{ACKNOWLEDGMENTS}

Klaudia Waszczykowska, Marta Węgierska and Roxana Drygała contributed equally to the work.

\section{CONFLICT OF INTEREST}

The authors declare no conflict of interest.

\section{REFERENCES}

1. Panagiotou M, Koulouris NG, Rovina N. Physical activity: a missing link in asthma care. J Clin Med 2020; 9: 706.

2. Hattab Y, Alhassan S, Balaan M, et al. Chronic obstructive pulmonary disease. Crit Care Nurs Q 2016; 39: 124-30.

3. Louie S, Zeki AA, Schivo M, et al. The asthma-chronic obstructive pulmonary disease overlap syndrome. Exp Rev Clin Pharmacol 2013; 6: 197-219.

4. Esakandari H, Nabi-Afjadi M, Fakkari-Afjadi J, et al. A comprehensive review of COVID-19 characteristics. Biol Proced Online 2020; 22: 19.

5. Stopsack KH, Mucci LA, Antonarakis ES, et al. TMPRSS2 and COVID-19: serendipity or opportunity for intervention? Cancer Discov 2020; 10: 779-82.

6. Ye Q, Wang B, Mao J. The pathogenesis and treatment of the "cytokine storm" in COVID-19. J Infect 2020; 80: 607-13.

7. Hojyo S, Uchida M, Tanaka K, et al. How COVID-19 induces cytokine storm with high mortality. Inflamm Regen 2020; 40: 37.

8. World Health Organization database: COVID-19 Weekly Epidemiological Update, https://www.who.int/publications/m/item/weekly-epidemiological-update---24-November-2020.

9. Omori R, Matsuyama R, Nakata Y. The age distribution of mortality from novel coronavirus disease (COVID-19) suggests no large difference of susceptibility by age. Sci Rep 2020; 10: 16642.

10. Xia Y, Li Q, Li W, et al. Elevated mortality of chronic diseases during COVID-19 pandemic: a cause for concern? Ther Adv Chronic Dis 2020; 11: 2040622320961590.

11. Park M, Cook AR, Lim JT, et al. A systematic review of COVID-19 epidemiology based on current evidence. J Clin Med 2020; 9: 967.
12. Pascarella G, Strumia A, Piliego C, et al. COVID-19 diagnosis and management: a comprehensive review. J Intern Med 2020; 288: 192206.

13. Calabrese F, Pezzuto F, Fortarezza F, et al. Pulmonary pathology and COVID-19: lessons from autopsy. The experience of European Pulmonary Pathologists. Virchows Archiv 2020; 477: 359-72.

14. Lam S, Lombardi A, Ouanounou A. COVID-19: a review of the proposed pharmacological treatments. Eur J Pharmacol 2020; 886: 173451.

15. Carmona-Bayonas A, Jimenez-Fonseca P, Sánchez Arraez Á, et al. Does active smoking worsen Covid-19? Eur J Intern Med 2020; 77 : 129-31.

16. Green I, Merzon E, Vinker S, et al. COVID-19 susceptibility in bronchial asthma. J Allergy Clin Immunol Pract 2021: 9: 684-92.

17. Usman MS, Siddiqi TJ, Khan MS, et al. Is there a smoker's paradox in COVID-19? BMJ Evidence-Based Medicine Published Online First 2020. doi: 10.1136/bmjebm-2020-111492.

18. Alqahtani JS, Oyelade T, Aldhahir AM, et al. Prevalence, severity and mortality associated with COPD and smoking in patients with COVID-19: a rapid systematic review and meta-analysis. PLoS One 2020; 15: e0233147.

19. World Health Organization database: https://www.who.int/newsroom/fact-sheets/detail/asthma Accessed [26.11.2020].

20. Kuruvilla ME, Lee FE, Lee GB. Understanding asthma phenotypes, endotypes, and mechanisms of disease. Clin Rev Allergy Immunol 2019; 56: 219-33.

21. Carli G, Cecchi L, Stebbing J, et al. Is asthma protective against COVID-19? Allergy 2020; 1: 10.1111/all.14426.

22. Zheng XY, Xu YJ, Guan WJ, et al. Regional, age and respiratory secretion-specific prevalence of respiratory viruses associated with asthma exacerbation: a literature review. Arch Virol 2018; 163: 845-3.

23. Kowalski ML, Bartuzi Z, Bręborowicz A, et al. Position statement of expert panel of the Polish Allergology Society on the management of patients with bronchial asthma and allergic diseases during SARS-Cov-2 pandemics. Alergol Pol 2020; 7: 57-63.

24. Javanmardi F, Keshavarzi A, Akbari A, et al. Prevalence of underlying diseases in died cases of COVID-19: a systematic review and meta-analysis. PLoS One 2020; 15: e0241265.

25. Wang Y, Chen J, Chen W, et al. Does asthma increase the mortality of patients with COVID-19? A systematic review and meta-analysis. Int Arch Allergy Immunol 2020; 22 : 1-7.

26. Ssentongo P, Ssentongo AE, Heilbrunn ES, et al. Association of cardiovascular disease and 10 other pre-existing comorbidities with COVID-19 mortality: a systematic review and meta-analysis. PLoS One 2020; 15: e0238215.

27. Riggioni C, Comberiati P, Giovannini M, et al. A compendium answering 150 questions on COVID-19 and SARS-CoV-2. Allergy 2020; 75: 2503-41.

28. Gour N, Wills-Karp M. IL-4 and IL-13 signaling in allergic airway disease. Cytokine 2015; 75: 68-78.

29. Schatz M, Hsu JW, Zeiger RS, et al. Phenotypes determined by cluster analysis in severe or difficult-to-treat asthma. J Allergy Clin Immunol 2014; 133: 1549-56.

30. Izquierdo JL, Almonacid C, González Y, et al. The impact of COVID-19 on patients with asthma. Eur Respir J 2020. doi: 10.1183/13993003.03142-2020.

31. Drygała R, Waszczykowska K, Węgierska M. A summary of novel biologics for asthma treatment. Alergol Pol 2020; 7: 98-105.

32. Global Initiative for Asthma, available from www.ginasthma.org, published in Fontana, WI, USA 2020. 
33. COVID-19 Treatment Guidelines Panel. Coronavirus Disease 2019 (COVID-19) Treatment Guidelines. National Institutes of Health. Available at https://www.covid19treatmentguidelines.nih.gov/. Accessed [26.11.2020].

34. Kumar K, Hinks TSC, Singanayagam A. Treatment of COVID-19exacerbated asthma: should systemic corticosteroids be used? Am J Physiol Lung Cell Mol Physiol 2020; 318: L1244-7.

35. Morais-Almeida M, Aguiar R, Martin B, et al. COVID-19, asthma, and biological therapies: what we need to know. World Allergy Organization J 2020; 13: 100126.

36. Jasik A, Marcinowska-Suchowierska E. Przewlekła obturacyjna choroba płuc. Postępy Nauk Medycznych 2009; 5: 340-4.

37. Aldonyte R, Bagdonas E, Raudoniute J, et al. Novel aspects of pathogenesis and regeneration mechanisms in COPD. Int J COPD 2015; 10: 995-1013.

38. Brusselle GG, Joos GF, Bracke KR. New insights into the immunology of chronic obstructive pulmonary disease. Lancet 2011; 378: 1015-26.

39. Barnes PJ. Cellular and molecular mechanisms of chronic obstructive pulmonary disease. Clin Chest Med 2014; 35: 71-86.

40. Dean E. Chronic obstructive pulmonary disease. Nursing Older People 2019; 29: 12.

41. Falk AJ, Minai OA, Mosenifar Z. Inhaled and systemic corticosteroids in chronic obstructive pulmonary disease. Proc Am Thorac Soc 2008; 5: 506-12.

42. Lakshmi S, Reddy A, Reddy R. Emerging pharmaceutical therapies for COPD. Int J Chron Obstruct Pulmon Dis 2017; 12: 2141-56.

43. Poole PJ. Role of mucolytics in the management of COPD. Int J Chron Obstruct Pulmon Dis 2006; 1: 123-8.

44. Rabe KF, Watz H. Chronic obstructive pulmonary disease. Lancet 2017; 389: 1931-40.

45. Hasan SS, Capstick T, Zaidi S, et al. Use of corticosteroids in asthma and COPD patients with or without COVID-19. Respir Med 2020; 170: 106045 .

46. Leung JM, Niikura M, Yang CWT, et al. COVID-19 and COPD. Eur Respir J 2020; 56: 2002108.

47. Simons SO, Hurst JR, Miravitlles M, et al. Caring for patients with COPD and COVID-19: a viewpoint to spark discussion. Thorax 2020; 75: 1035-9.

48. Attaway A, Hatipoğlu U. Management of patients with COPD during the COVID-19 pandemic. Cleve Clin J Med 2020. doi: 10.3949/ ccjm.87a.ccc007.

49. (c) 2020, Global Initiative for Chronic Obstructive Lung Disease, available from www.goldcopd.org, published in Fontana, WI, USA.

50. Wang L, Foer D, Bates DW, et al. Risk factors for hospitalization, intensive care, and mortality among patients with asthma and COVID-19. J Allergy Clin Immunol 2020; 146: 808-12.

51. Aksan F, Nelson EA, Swedish KA. A COVID-19 patient with intense burning pain. J Neurovirol 2020; 26: 800-1.

52. Lau J, Khoo HW, Hui, et al. Atypical chest computed tomography finding of predominant interstitial thickening in a patient with Coronavirus disease 2019 (COVID-19) pneumonia. Am J Case Rep 2020; 21: e926781.

53. Leung JM, Yang CX, Tam A, et al. ACE-2 expression in the small airway epithelia of smokers and COPD patients: implications for COVID-19. Eur Respir J 2020; 55: 2000688.

54. Jackson DJ, Busse WW, Bacharier LB, et al. Association of respiratory allergy, asthma and expression of the SARS-CoV-2 receptor, ACE2. J Allergy Clin Immunol 2020; 146: 203-6.e3.
55. Branco ACCC, Sato MN, Alberca RW. The possible dual role of the ACE2 receptor in asthma and Coronavirus (SARS-CoV2) infection. Front Cell Infect Microbiol 2020; 10: 550571.

56. Bouazza B, Hadj-Said D, Pescatore KA, et al. Are patients with asthma and COPD preferred targets of COVID-19? Tuberc Respir Dis 2021; 84: 22-34.

57. Saheb Sharif-Askari N, Saheb Sharif-Askari F, Alabed M, et al. Airways expression of SARS-CoV-2 receptor, ACE2, and TMPRSS2 is lower in children than adults and increases with smoking and COPD. Mol Ther Methods Clin Dev 2020; 18: 1-6.

58. Kesic MJ, Hernandez M, Jaspers I. Airway protease/antiprotease imbalance in atopic asthmatics contributes to increased influenza A virus cleavage and replication. Respir Res 2012; 13: 82.

59. Kermani N, Song WJ, Lunt A, et al. Airway expression of SARS$\mathrm{CoV}-2$ receptor, $\mathrm{ACE} 2$, and proteases, TMPRSS2 and furin, in severe asthma. medRxiv 2020. doi: 10.1101/2020.06.29.20142091. 